\title{
SEPAK TERJANG ADE MOELYANA DALAM MERINTIS SENI LUKIS DARI LIMBAH PELEPAH PISANG DI CIMAHI TAHUN 1969-2010
}

\author{
Junia Triani, Murdiyah Winarti, Eryk Kamsori Moch \\ Universitas Pendidikan Indonesia
}

\begin{abstract}
This study aims to explain the Ade Moelyana struggle's in developing the art painting of wasted banana stalks in Cimahi from 1969 to 2010. The main issue discussed was "How was the Developments Art Painting of Wasted Banana Stalks in Cimahi from 1969-2010?". The method used is the historical method through four phases of heuristics, criticism, interpretation and historiography. Based on the research results, the art painting of wasted banana stalks has existed since 1969. It is Ade Moelyana, a painter who introduced art painting of wasted banana stalks in Cimahi. In its development, this painting has been through the ups and downs, in early 1969, this painting was not accepted by most people in Cimahi even this painting is considered as junk. Then in the year 2000, the painting is experiencing the peak of development. This is because not only do marketing painting around Cimahi but abroad as well. Painting of wasted banana stalks can be used as a creative economic sector and creates jobs. Lack of awareness of the various parties to make this painting became dormant.
\end{abstract}

Keywords: Art Painting of Banana Stalks, Ade Moelyana, Creative Economy

\begin{abstract}
Penelitian ini bertujuan untuk menjelaskan mengenai sepak terjang Ade Moelyana dalam mengembangkan seni lukis dari limbah pelepah pisang di Cimahi dari tahun 1969-2010. Masalah utama yang dibahas adalah "Bagaimana Perkembangan Seni Lukis Dari Limbah Pelepah Pisang di Cimahi Pada Tahun 1969-2010?". Metode yang digunakan adalah metode historis yang melalui empat tahap yaitu heuristik, kritik, interpretasi dan historiografi. Berdasarkan dari hasil penelitian, seni lukis dari limbah pelepah pisang telah ada sejak tahun 1969. Adalah Ade Moelyana seorang pelukis yang telah mengenalkan seni lukis dari limbah pelepah pisang di Cimahi. Dalam perkembangannya seni lukis ini mengalami pasang surut, pada awal tahun 1969 seni lukis ini tidak diterima oleh sebagian besar masyarakat di Cimahi bahkan lukisan ini dianggap sebagai sampah. Baru pada tahun 2000 seni lukis ini mengalami puncak perkembangan, hal ini karena pemasaran lukisan tidak hanya dilakukan di sekitar Cimahi melainkan sampai mancanegara. Seni lukis dari limbah pelepah pisang dapat dijadikan sebagai sektor ekonomi kreatif dan dapat menciptakan lapangan pekerjaan. Kurangnya kesadaran dari berbagai pihak menjadikan seni lukis ini menjadi terbengkalai.
\end{abstract}

ABSTRAK

Kata Kunci : Seni Lukis Pelepah Pisang, Ade Moelyana, Ekonomi Kreatif

Author correspondence

Email:juju.triani@yahoo.com

Available online at http: // http://ejournal.upi.edu/index.php/factum 


\section{PENDAHULUAN}

Cimahi merupakan salah satu kota yang terletak yang berada di Jawa Barat. Letaknya yang berada di tengah-tengah antara Kabupaten Bandung dan Kabupaten Bandung Barat, menjadikan kota Cimahi ini dijadikan sebagai tempat singgah oleh sebagian para wisatawan. Cimahi memiliki berbagai macam keunikan, salah satunya yaitu beragamnya kesenian yang dimiliki oleh kota Cimahi. Salah satu wisata kesenian yang terkenal adalah lembur batik, destinasi wisata ini menawarkan wisata seni batik.

Kesenian yang dikembangkan di Cimahi tidak hanya seni batik saja, kesenian lain yang juga dikembangkan yaitu seperti kesenian tradisional yang meliputi tari Jaipong, tari keurseus, sisingaan, angklung, kliningan, gondang, dll. Dalam hal ini perkembangan tidak hanya dipusatkan pada kesenian tradisional saja, akan tetapi seni rupa pun turut mendapatkan perhatian dari para seniman di Cimahi untuk dikembangkan. Salah satu seni rupa yang dikembangkan di Cimahi yaitu seni lukis dari limbah pelepah pisang. Seni lukis dari limbah pelepah pisang ini merupakan salah satu seni lukis yang memiliki keunikan tersendiri. Hal ini karena bahan dasar dalam pembuatan seni lukis ini tidak menggunakan cat air seperti pada lukisan-lukisan pada umumnya, melainkan menggunakan limbah dari pelepah pisang sebagai bahan dasar utamanya.

Seni lukis dari limbah pelepah pisang di Cimahi muncul pertama kali pada tahun 1969. Berawal dari keprihatinan salah satu warga Cimahi yang sedang melakukan perjalanan ke Gunung Burangrang. Dalam perjalanan Ade Melihat pohon pisang yang kecil dan terhalangi oleh pohonpohon besar yang berada di sekelilingnya, sehingga pohon pisang tersebut tidak mendapatkan sinar matahari. Bagian dari pelepah pisang tersebut terkelupas dan berjatuhan ke dasar tanah, pelepah pisang tersebut sama sekali tidak memiliki daya tarik bahkan dianggap hanya sampah. Pelepah pisang yang berjatuhan lalu dikumpulkan dan disusun di atas tanah sehingga membentuk satu gambar yang indah. Dari sini muncul ide untuk membuat lukisan yang terbuat dari limbah pelepah pisang.

Seni lukis dari limbah pelepah pisang ini dapat dikategorikan sebagai seni lukis kolase. Hal ini karena pengerjaan dalam lukisan pelepah pisang ini dengan cara menempelkan potongan-potongan dari limbah pelepah pisang ke media triplek. Seperti yang dikemukakan Susanto dalam (2002, hlm. 63) kolase adalah salah satu teknik seni dengan cara menempel bahanbahan selain cat seperti kaca, logam, dan sebagainya pada bidang datar. Teknik kolase ini masuk ke dalam airan-aliran kubisme yaitu kubisme sintetik. Tipe kubisme sintetik ini muncul dari teknik baru "papiers colles" (kolase kertas) yang dimulai oleh Braque pada musim seni pada tahun 1912, atau juga yang dikenal dengan dengan teknik tempel. Dalam hal ini yang menjadi pertimbangan utama kubisme sintetik yaitu konstruksi gambar, kemudian menempel potongan-potongan, garis bidang bentuk, dan warna sehingga menjadi suatu kesatuan utuh (Kartika, D, 2004, hlm.80).

Dalam perkembangannya seni lukis dari limbah pelepah pisang ini mengalami pasang surut. Seperti pada awal perkembangannya, lukisan yang 
terbuat dari limbah pelepah pisang ini tidak serta merta dapat diterima langsung oleh masyarakat di Cimahi. Bahkan banyak yang beranggapan bahwa lukisan tersebut hanya sampah dan tidak layak untuk dinilai sebagai karya seni. Beberapa Seniman yang ada di Cimahi juga mengatakan bahwa lukisan tersebut bukan merupakan sebuah lukisan melainkan kerajinan tangan. Berkat kerja keras dan melewati diskusi yang panjang antara Ade Moelyana dengan beberapa seniman di Cimahi, akhirnya seni lukis yang terbuat dari limbah pelepah pisang dapat diterima sebagai lukisan.

Lukisan dari limbah pelepah pisang mulai dijual pada tahun 1971, penjualan dilakukan dengan cara ekspedisi ke berbagai daerah yang ada di Indonesia. Daerah tersebut seperti Bali, Yogyakarta, Semarang, dan Jakarta. Ekspedisi bertujuan untuk memajang hasil lukisan dan melakukan demonstrasi cara melukis dengan menggunakan limbah dari pelepah pisang. Hal ini dilakukan agar menarik perhatian para wisatawan maupun warga sekitar. Seperti pada saat ekspedisi di Bali, salah satu warga Perancis yang sedang berlibur di Bali, tertarik dengan demonstrasi yang dilakukan oleh Ade Moelyana. Warga Perancis tersebut lalu menawarkan kepada Ade untuk melakukan demonstrasi di negaranya dengan biaya akan ditanggung semua.

Pada tahun 2000, seni lukis ini mengalami puncak perkembangan, pasalnya lukisan tidak hanya dipasarkan di dalam negeri saja melainkan sampai mancanegara seperti Australia, Inggris, Jepang, Jerman, Perancis, USA dan Malaysia. Seni lukis ini telah mendapatkan berbagai penghargaan seperti penghargaan dari Gubernur Jawa Barat, Anugrah Aryasatya Budaya, penghargaan daur ulang terbaik, dll. Keberhasilan yang diperoleh Ade Moelyana ternyata menjadi motivasi banyak orang untuk ikut serta dalam membuat lukisan yang terbuat dari limbah pelepah pisang. Hal ini dibuktikan dengan banyaknya warga baik berasal dari Cimahi maupun luar Cimahi yang mengikuti pembinaan keterampilan yang diberikan oleh Ade Moelyana.

Senilukis darilimbah pelepah pisang ini memiliki potensi yang cukup menjanjikan bagi siapa saja yang menekuninya. Lukisan ini pula dapat memberikan lapangan pekerjaan bagi masyarakat di kota Cimahi, selain itu pula seni lukis pelepah pisang ini dapat dijadikan sebagai ekonomi kreatif. Meskipun peserta yang mengikuti pembinaan ini jumlahnya terhitung banyak, akan tetapi pada kenyataannya seni lukis dari limbah pelepah pisang ini tetap terbengkalai, terutama ketika pelukis Ade Moelyana memiliki kesibukkan baru menjadi seorang Cosplayer, yaitu sebuah kegiatan meniru karakter tokoh kartun Jepang. Kurangnya perhatian dari berbagai pihak seperti pelukis, warga sekitar maupun pemerintah menjadikan seni lukis dari limbah pelepah pisang ini menjadi terbengkalai, padahal jika dikembangkan dengan serius seni lukis ini dapat memberikan potensi ekonomi yang cukup menjanjikan.

Berdasarkan pengamatan tersebut, penulistertarikuntukmembahas mengenai perkembangan seni lukis dari limbah pelepah pisang di Cimahi tahun 19692010, terutama mengenai sepak terjang Ade Moelyana dalam mengembangkan seni lukis dari limbah pelepah pisang. Alasan batasan periode pada tahun 1969- 
2010, yaitu pada tahun 1969 merupakan awal perkembangan seni lukis dari limbah pelepah pisang dan pada tahun 2010 pelukis yang menekuni lukisan ini mulai berhenti membuat lukisan dari limbah pelepah pisang, walaupun tidak berhenti secara total. Ada beberapa alasan yang membuat penulis merasa tertarik untuk mengkaji lebih dalam lagi mengenai perkembangan seni lukis dari limbah pelepah pisang, yaitu seni lukis ini merupakan karya seni yang unik. Seni lukis ini memiliki potensi ekonomi yang cukup menjanjikan bagi perekonomian warga sekitar di kota Cimahi, akan tetapi pada kenyataannya seni lukis ini justru terabaikan. Diharapkan dengan adanya kajian ini semua pihak dapat memanfaatkan potensi dari lukisan pelepah pisang secara baik.

\section{METODE PENELITIAN}

Metode yang akan digunakan dalam penelitian ini adalah menggunakan metode historis. Hal ini dilakukan karena masalah teknik, dan cara yang akan penulis teliti bersifat kesejarahan Menurut Louis Gottschlak dalam (Abdurahman, 2007, hlm. 54) metode sejarah mengandung pengertian sebagai "proses menguji dan menganalisis kesaksian sejarah guna menemukan data yang autentik dan dapat dipercaya, serta menuliskan hasilnya berdasarkan fakta yang telah diperoleh yang disebut historiografi.

Sebelum melakukan penelitian, penulis terlebih dahulu melakukan tahapan-tahapan seperti pemilihan topik, penyusunan rencana penelitian, bimbingan dan konsultasi. Setelah tahapan tersebut telah dilakukan barulah dilakukan pelaksanaan penelitian. Menurut Ismaun dalam (2005, hlm. 34), prosedur sejarawan dalam melakukan penelitian sejarah terdiri atas empat tahap, yaitu heuristik, kritik, interpretasi, dan historiografi. Pada tahap heuristik ini penulis mengumpulkan sumber tertulis dengan cara mengunjungi perpustakaan-perpustakaan yang ada di Bandung serta menggunkan beberapa sumber dari koleksi pribadi. Pengumpulan sumber tidak hanya terbatas pada sumber tertulis, melainkan juga mengumpulkan sumber lisan. Pengumpulan sumber lisan dilakukan karena terbatasnya sumber tertulis yang membahas mengenai seni lukis dari limbah pelepah pisang. Untuk mengumpulkan data-data melalui sumber lisan, penulis menggunakan teknik wawancara. Dalamhaliniteknikwawancara diharapkan dapat mempermudah penulis dalam mendapatkan informasi-informasi yang dibutuhkan.

Tahap kedua yang dilakukan dalam penelitian sejarah adalah kritik sumber. Tahapan ini dilakukan setelah penulis memperoleh sumber-sumber baik berupa sumber lisan ataupun sumber tertulis. Kritik sumber merupakan kegiatan untuk memilih dan menyeleksi sumbersumber manakah yang dapat dijadikan sebagai bahan untuk menyusun skripsi. Di dalam metode sejarah, ada dua tahap yang dilakukan dalam kritik sumber, yaitu kritik eksternal dan internal. Kritik Eksternal Pada tahap ini penulis menguji aspek-aspek di luar sumber sejarah. Kritik eksternal ini bertujuan untuk memilih dan memilah beberapa sumber yang telah penulis dapatkan, apakah sumber tersebut layak digunakan atau tidak untuk dijadikan sebagai sumber penunjang dalam penelitian skripsi.

Penulis melakukan kritik eksternal terhadap buku yang akan digunakan sebagai sumber penulisan. Penulis memilah sumber buku yang ditulis 
oleh orang-orang yang berkompeten di Bidangnya seperti buku yang ditulis oleh Sanento Yuliman dan Moelyono. Keduanya merupakan tokoh seniman yang terlibat dalam perkembangan seni rupa di Indonesia. Sehingga buku yang ditulis oleh keduanya dapat dijadikan sumber yang dapat dipertanggungjawabkan. Kritik eksternal tidak hanya dilakukan pada sumber tertulis saja, melainkan juga pada sumber lisan. Kritik eksternal yang dilakukan terhadap sumber lisan yaitu dilakukan pada Ade Moelyana (69 tahun), Danny (20 tahun). Keduanya merupakan pelukis yang masih aktif dalam mengembangkan seni lukis dari limbah pelepah pisang. Ade Moelyana merupakan pelukis utama atau perintis seni lukis dari limbah pelepah pisang di Cimahi, walaupun demikian fisik Ade Moelyana masih sehat, selain itu pula ingatan dari Ade Moelyana sangat penting untuk mengingat kembali peristiwa yang dialami olehnya. Ingatan dari Ade Moelyana sangat penting untuk menyampaikan dan menjelaskan mengenai perkembangan seni lukis dari limbah pelepah pisang.

Buku yang akan penulis kritik dalam tahapan kritik internal adalah buku yang berjudul Dua Seni Rupa Sepilihan Tulisan Sanento Yuliman karya Sanento Yuliman. Dalam buku tersebut dijelaskan mengenai perkembangan dari seni rupa di Indonesia. Selain itu pula, dalam buku tersebut dijelaskan mengenai makna dari setiap pameran lukisan. Buku lain yang melalui tahapan kritik internal yaitu buku yang berjudul Seni Rupa Penyadaran karya Moelyono. Secara garis besar buku tersebut menjelaskan mengenai cita-cita seni lukis untuk rakyat atau yang lebih dikenal dengan demokratisasi seni.
Penulis juga melakukan tahapan kritik internal terhadap hasil wawancara yang diperoleh dari dua narasumber utama. Kritik ini dilakukan agar kebenaran informasi yang diperoleh dari narasumber dapat dipertanggungjawabkan. Dalam hal ini penulis memperoleh fakta yang berkaitan dengam perkembangan seni lukis dari limbah pelepah pisang di Cimahi. berdasarkan hasil wawancara terdapat kesamaan informasi mengenai perkembangan seni lukis dari limbah pelepah pisang, yang diperoleh dari Ade Moelyana (69 tahun) dan Dany (20 tahun).

Setelah penulis mengumpulkan sumber dan melakukan kritik eksternal dan internal, selanjutnya penulis melakukan tahap interpretasi atau penafsiran terhadap sumber. Tahap penafsiran ini dari data-data yang telah melalui tahap kritik menjadi fakta-fakta yang diperoleh dalam penelitian. Setelah data-data tersebut dirumuskan dan disimpulkan lalu kemudian setelah itu ditafsirkan. Setiap fakta yang ditemukan dihubungkan dengan fakta lain, sehingga menjadi sebuah rekontruksi yang menggambarkan perkembangan seni lukis dari limbah pelepah pisang di Cimahi tahun 1969-2010 sebagai potensi ekonomi yang terabaikan.

Tahap terakhir atau tahap keempat dalam penelitian sejarah adalah historiografi. Historiografi merupakan kegiatan yang tidak bisa dipisahkan dengan tahap interpretasi, keduanya dilakukan secara bersamaan. Pada bagian ini penulis akan menyajikan hasil temuantemuan dari berbagai sumber yang penulis dapatkan ketika proses penelitian, hasil temuan tersebut kemudian dianalisis dan diseleksi kemudian direkonstruksi menjadi sebuah penulisan sejarah. 


\section{HASIL PENELITIAN DAN PEMBAHASAN}

Seni lukis dari limbah pelepah pisang merupakan hasil dari kreativitas salah seorang warga Cimahi tepatnya di Jalan Amir Mahmud, Kecamatan Karang Mekar Cimahi Tengah. Adalah Ade Moelyana atau yang akrab disapa Abah Moel yang telah mengenalkan seni lukis dari limbah pelepah pisang di Cimahi. Berawal dari keprihatinannya pada saat melakukan perjalanan ke Gunung Burangrang bersama komunitasnya yaitu Yana Buana pada bulan Maret 1969. Pada saat itu Ade Moelyana melihat pohon pisang yang terhalangi oleh pohonpohon besar yang ada disekitarnya. Pohong pisang tersebut sama sekali tidak mendapatkan sinar matahari, karena terhalangi oleh pohonpohon besar. Bagian dari pohon pisang tersebut terkelupas dan berjatuhan di tanah, melihat hal tersebut Ade Moelyana mengumpulkan pelepah pisang yang terkelupas.

Pelepah pisang yang telah dikumpulkan lalu disobek-sobek dan disusun diatas tanah, susunan pelepah pisang tersebut ternyata membentuk suatu gambar yang indah. Sobekan-sobekan dari limbah pelepah pisang ini terdiri dari berbagai warna yang berbeda. Atas dasar inilah muncul ide untuk membuat seni lukis yang terbuat dari limbah pelepah pisang. Pelepah pisang yang dianggap oleh sebagian besar masyarakat sebagai sampah yang tidak terpakai dan sama sekali tidak memiliki potensi ekonomi, dapat diubah menjadi karya seni yang memiliki nilai ekonomi yang tinggi.

Pada tahun 1969, sejak duduk dibangku kuliah tingkat dua di Administrasi Niaga Negeri, Ade Moelyana mulai beralih melukis dengan menggunakan limbah pelepah pisang. Hal ini karena sebelum menekuni seni lukis dari limbah pelepah pisang, Ade Moelyana melukis dengan menggunakan cat air seperti pelukis pada umumnya. Peralihan ini dilakukan karena memang di Cimahi belum ada yang menekuni seni lukis yang terbuat dari limbah pelepah pisang. Pembuatan seni lukis dari limbah pelepah pisang ini menggunakan lem sebagai media untuk penempelan limbah pelepah pisang. Pada awalnya lem yang digunakan bukan lem kayu yang pada umumnya digunakan, hal ini karena pada tahun 1969 lem kayu belum tersedia. Sehingga, lem yang digunakan untuk menempel limbah pelepah pisang yaitu dengan lem yang terbuat dari benang layang-layang yang telah dipanaskan. Benang layang yang telah dipanaskan tersebut kemudian dioleskan ke dalam limbah pelepah pisang yang akan digunakan sebagai bahan untuk melukis. Penggunaan lem ini harus dilakukan ketika lem tersebut masih dalam keadaan panas, hal ini agar lem tersebut tidak berubah menjadi kering dan keras, karena jika lem tersebut kering maka tidak dapat digunakan (Ade Moelyana, Wawancara tanggal 10 Agustus 2015).

Lukisan pertama yang dibuat oleh Ade Moelyana ini adalah lukisan bertemakan pemandangan alam. Lukisan tersebut berhasil diselesaikan dalam kurun waktu 3-4 bulan. Tema pemandangan alam dipilih sebagai karya pertama kali dibuatnya karena dalam hal ini Ade beranggapan bahwa pelepah pisang ini berasal dari alam, sehingga dia ingin menggunakan objek alam untuk karya pertamanya. Lukisan pertama yang dibuatnya belum melewati tahap pengasaman, sehingga warna yang dikeluarkan dari limbah pelepah pisang ini masih sedikit. Dalam hal ini juga teknik yang digunakan oleh Ade Moelyana masih terbatas sehingga tekstur kasar dari lukisan pertamanya sangat terlihat. Lukisan pertama yang dibuat tidak langsung dijual, akan tetapi dijadikan sebagai kenang-kenangan. 
Pada awalnya, seni lukis dari limbah pelepah pisang ini tidak serta merta dapat diterima langsung oleh masyarakat di sekitar kota Cimahi. Banyak yang menganggap bahwa lukisan yang terbuat dari limbah pelepah pisang ini aneh dan hanya terbuat dari sampah, sehingga tidak layak dikatakan sebagai karya seni. Bahkan seni lukis dari limbah pelepah pisang ini sempat ditolak oleh beberapa galeri yang ada di Bandung, karena lukisan hasil karya Ade Moelyana ini bukan merupakan hasil karya pelukis profesional sekelas Affandi.

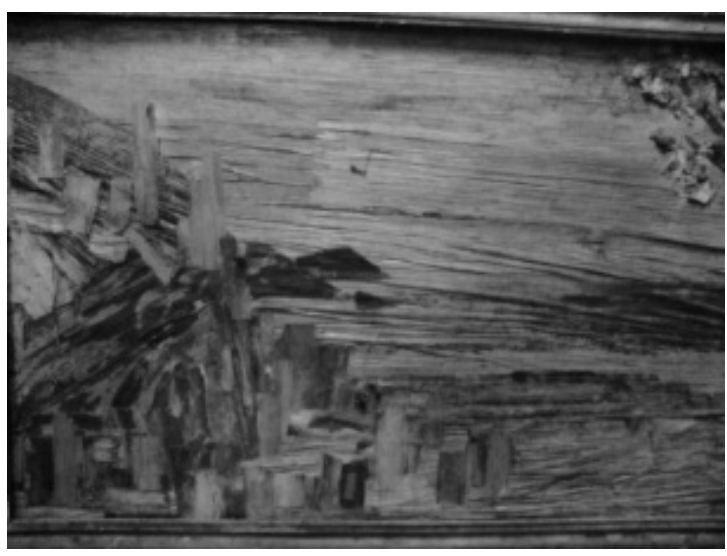

Gambar 4.1

Lukisan Pertama Ade Moelyana

(sumber : Dokumentasi Pribadi, tanggal 28 Oktober 2015)

Seiring berjalannya waktu, pada kurun waktu 1971-1972 lukisan dari limbah pelepah pisang ini mulai diminati. Pasalnya, pada kurun waktu ini lukisan dari limbah pelepah pisang ini mulai dijual, akan tetapi penjualan dilakukan hanya di sekitar Cimahi saja. Setelah penjualan dilakukan, lukisan dari limbah pelepah pisang banyak diminati, karena banyak orang yang mengetahui dari mulut ke mulut. Hal ini menandakan awal dari perkembangan seni lukis dari limbah pelepah pisang di Cimahi.

Pada tahun 1981, Ade Moelyana melakukan ekspedisi keluar Jawa seperti misalkan Bali. Ekspedisi ini dilakukan bersama teman-temannya, untuk menjual lukisan yang telah dibuatnya. Selain menjual lukisannya, ekspedisi ini juga dilakukan untuk melakukan demonstrasi cara melukis dengan menggunakan limbah dari pelepah pisang. Sesampainya di Bali, Ade bertemu dengan orang yang berasal dari Perancis. Orang tersebut tertarik untuk melukis dengan menggunakan limbah dari pelepah pisang, dan menawarkan kepada Ade Moelyana untuk melakukan demonstrasi melukis di negaranya dengan biaya akan ditanggung semua.

Krisis moneter yang terjadi pada tahun 1997, menjadikan berbagai usaha yang ada di daerah-daerah di Indonesia mengalami kebangkrutan. Hal ini karena mahalnya bahan baku dan kurangnya modal untuk mempertahankan usaha yang telah mereka jalani. Hal ini juga terjadi pada perkembangan seni lukis pelepah pisang di Cimahi. Terbatasnya modal untuk mencari pelepah pisang ke berbagai daerah seperti Banjar, Garut, Tasik, Cianjur, dan Purwakarta, menjadikan seni lukis dari limbah pelepah pisang ini sempat terhenti. Bahkan, karena adanya krisis moneter ini sempat membuat pelukis Ade Moelyana vakum dalam membuat dan menjual lukisan dari limbah pelepah pisang ini.

Pada tahun 2000, lukisan dari limbah pelepah pisang ini mengalami perkembangan yang cukup pesat. Hal ini karena penjualan dari lukisan pelepah pisang ini tidak hanya dilakukan di Cimahi saja, melainkan juga meluas hingga mancanegara seperti USA, Australia, Inggris, Jerman, Jepang, Perancis, dan Malaysia. Selain itu pula, seni lukis dari limbah pelepah pisang ini pernah mengikuti lomba tingkat dunia dan telah masuk ke peringkat 25 besar. Lomba tidak sempat dilanjutkan, karena terbatasnya 
modal untuk menyelesaikan lukisan tersebut (Ade Moelyana, Wawancara tanggal 28 Oktober 2015).

Seni lukis dari limbah pelepah pisang ini memiliki potensi ekonomi kreatif. Menurut KEA Europan Affairs dalam (Suryana, 2011, 37-38) ada empat jenis kreativitas yang membentuk ekonomi kreatif, yaitu sebagai berikut :

1. Kreativitas ilmu pengetahuan (Scientific creatifity)

2. Kreativitas ekonomi (Economic creatifity)

3. Kreativitas budaya (Cultural creativity)

4. Kreativitas teknologi (Technology creatifity)

Kreativitas budaya memiliki makna yaitu kreativitas dalam bentuk seni seperti kesenian, film, artistik dan seni lainnya. Industri kreatif oleh UNESCO didefinisikan sebagai industri yang mengkombinasikan kreasi, produksi, komersialisasi, baik intangible maupun cultural yang tercipta secara alamiah. Industri kreatif adalah industri yang menggunakan kreativitas, keterampilan (skill), dan kecakapan (talent) yang secara potensial dapat menciptakan kekayaan dan lapangan pekerjaan.

Berdasarkan pengertian diatas, telah menguatkan penulis bahwa seni lukis dari limbah pelepah pisang ini dapat dikategorikan sebagai salah satu potensi ekonomi kreatif. Hal ini karena seni lukis dari limbah pelepah pisang ini merupakan hasil dari ide kreatifitas salah satu pelukis di Cimahi, yaitu Ade Moelyana. Ide kreatifnya itu adalah mengubah limbah dari pelepah pisang menjadi suatu karya yang memiliki potensi ekonomi yang cukup tinggi. Jika seni lukis dari limbah pelepah pisang ini dikembangkan secara serius, maka seni lukis dari limbah pelepah pisang ini dapat dijadikan sebagai lapangan kerja bagi masyarakat kita Cimahi, khususnya bagi warga di sekitar jalan Amir Mahmud

Inovasi yang dilakukan oleh Ade Moelyana dalam pembuatan seni lukis dari limbahpelepahpisangadalah meliputitema atau objek lukisan. Hal ini dilakukan agar menghindari kejenuhan dalam pembuatan lukisan dan agar tema dalam lukisan dari limbah pelepah pisang ini lebih bervariasi. Jika pada awal perkembangannya, tema yang dibuat hanya pemandangan saja akan tetapi juga dibuat lukisan dengan tema hewan semi flat dan replika patung, manusia, wayang, transportasi, dan bangunan. Lukisan dengan tema semi flat yaitu sebuah lukisan yang penempelan pelepah pisangnya langsung ditempel ke dalam triplek sehingga menyatu dengan tripleknya, sedangkan untuk hewan dengan tema replika patung yaitu pembuatan replika hewan yang diaplikasikan ke dalam lukisan pelepah pisang. Perkembangan tema dari lukisan pelepah pisang ini akan dituangkan ke dalam tabel sebagai berikut:

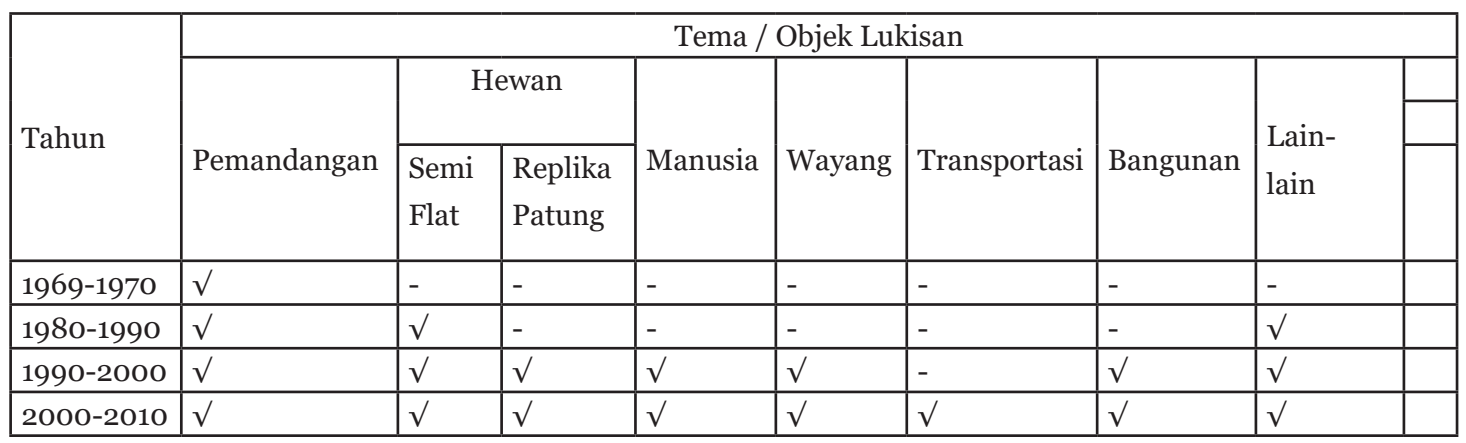


FACTUM: JURNAL SEJARAH DAN PENDIDIKAN SEJARAH, VOL. 7 NO. 1, 2018

ISSN: 2302-9889, E.ISSN: 2615-515X

Perkembangan Seni Lukis Pelepah Pisang Berdasarkan Tema

Sumber: Data diolah berdasarkan hasil penelitian wawancara dengan Ade Moelyana pada Bulan Oktober-Desember 2015

Ket $: \sqrt{ }$ sudah diproduksi - belum diproduksi Lain-lain : inovasi selain pembuatan lukisan.

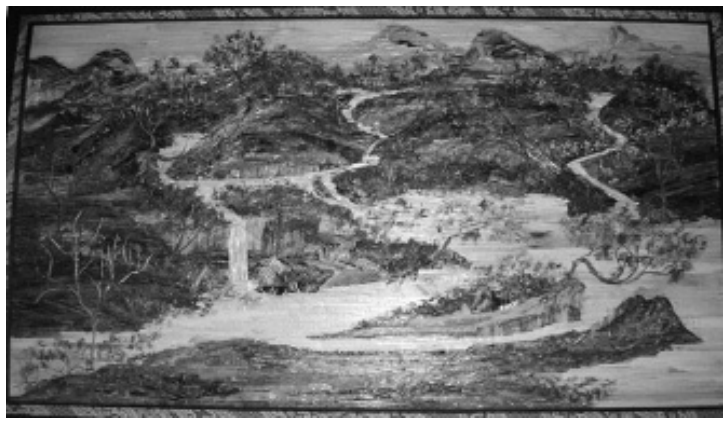

\section{Gambar 4.2}

Objek lukisan dengan tema pemandangan (sumber : Dokumentasi Pribadi, tanggal 28 Oktober 2015

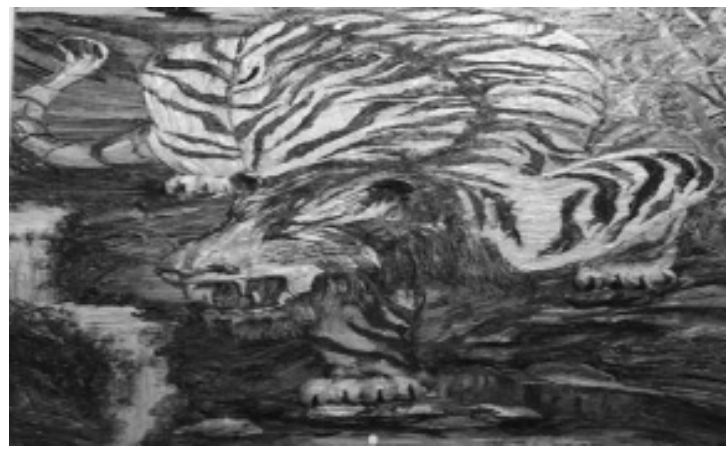

\section{Gambar 4.3}

Objek lukisan dengan tema hewan semi flat (sumber : Dokumentasi Pribadi, tanggal 28 Oktober 2015)

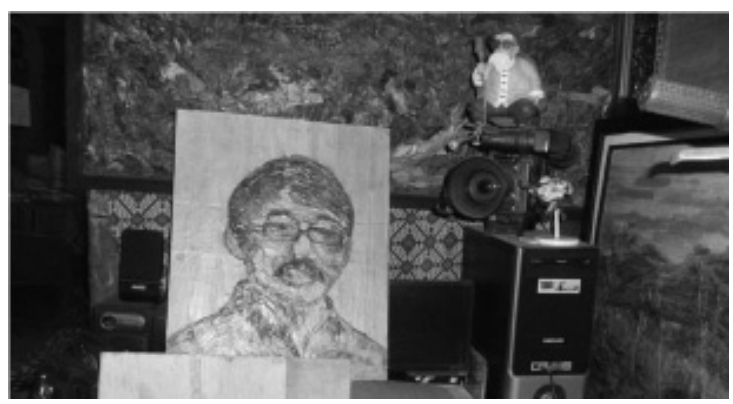

\section{Gambar 4.4}

Objek lukisan dengan tema Manusia (Sumber : Dokumentasi pribadi, tanggal 22 Desember 2015)

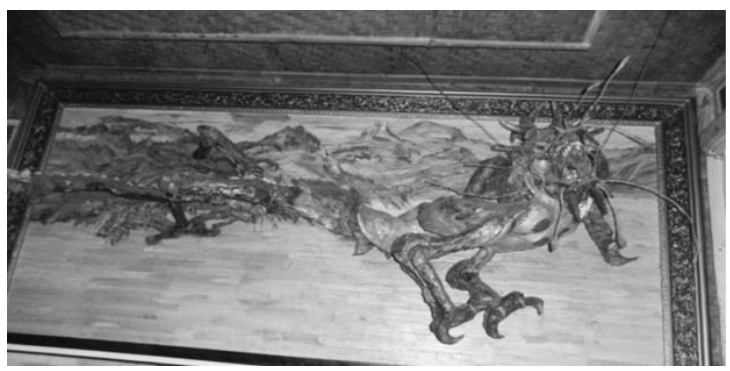

\section{Gambar 4.5}

Objek dengan tema replika patung Hewan (Sumber : Dokumentasi Pribadi, tanggal 10 November 2015)

Perkembangan Seni lukis pelepah pisang di Cimahi Berdasarkan Wilayah Pemasaran pada tahun 1969-2010

\begin{tabular}{|l|l|}
\hline Tahun & Wilayah Pemasaran \\
\hline 1969 & - \\
\hline $1971-1972$ & Sekitar Cimahi \\
\hline $1981-1982$ & Jakarta, Yogyakarta, Surabaya, Bali, Perancis \\
\hline $1983-1984$ & Bali \\
\hline $1985-1986$ & Bali, Cimahi \\
\hline $1997-1998$ & - \\
\hline $2000-2001$ & Cimahi, Malaysia, Inggris, Amerika, Jerman, Jepang dan Australia \\
\hline $2002-2010$ & Sekitar Cimahi ${ }^{*}$ \\
\hline
\end{tabular}


Sumber : Data diolah berdasarkan hasil penelitian dan wawancara dengan Ade Moelyana pada bulan Oktober-November 2015.

Keterangan : * penjualan terbatas

Dari tabel di atas menjelaskan mengenai perkembangan seni lukis berdasarkan wilayah pemasaran. Padatahun 1969, lukisan dari pelepah pisang ini tidak langsung dijual, akan tetapi karya pertamanya dijadikan sebagai kenang-kenangan. Pada tahun 19711972 penjualan mulai dilakukan, penjualan dilakukan hanya di sekitar Cimahi saja, baru pada tahun 1981-1982 pemasaran mulai dilakukan diluar Cimahi. Daerah tersebut meliputi Jakarta, Yogyakarta, Surabaya, Bali, Perancis. Penjualan sempat terhenti pada kisaran tahun 1997-1998, hal ini karena terjadinya krisis moneter di Indonesia. Peristiwa tersebut menjadikan pelukis Ade Moelyana merasakan drop dalam pembuatan lukisan dari limbah pelepah pisang. Bahkan Ade Moelyana sempat mengalami kevakuman dalam membuat lukisan. Barulah pada tahun 2000, Ade Moelyana mencoba bangkit dan mulai kembali menekuni seni lukis dari limbah pelepah pisang.

Banyaknya media cetak maupun elektronik yang meliputi mengenai seni lukis dari limbah pelepah pisang ini semakin menjadikan lukisan ini semakin banyak diminati baik oleh warga di sekitar Cimahi maupun di luar Cimahi. Puncaknya seni lukis ini tidak hanya dipasarkan di Cimahi saja, melainkan sampai ke mancanegara seperti Malaysia, Inggris, Amerika, Jerman, Jepang dan Australia. Lukisan dari limbah pelepah pisang ini bahkan telah diliput oleh beberapa televisi nasional. Berkat peliputannya inilah semakin banyak warga yang berdatangan ke Saung Pongpok Bodogol 69. Orang-orang yang berdatangan tidak hanya warga sekitar Cimahi saja, akan tetapi dari luar Cimahi, bahkan turis asing pun pernah mendatangi tempat tersebut. Mereka berdatangan untuk belajar melukis dengan menggunakan limbah pelepah pisang. Selain itu pula orang-orang yang berdatangan mulai dari kalangan anak-anak hingga orang dewasa (Ade Moelyana \& Dani, Wawancara tanggal 10 November 2015).

Dalam hal ini seni lukis dari limbah pelepah pisang ini merupakan salah satu seni yang dapat dikategorikan ke dalam seni lingkungan. Hal ini karena penggunaan materi dalam pembuatan seni lukis ini adalah menggunakan limbah dari pelepah pisang. Seni lukis dari limbah pelepah pisang ini merupakan bentuk nyata dalam melakukan gerakan sadar lingkungan. Seperti yang dilakukan oleh para seniman mantan gerakan seni rupa baru pada tahun 80-an. Para seniman ini mulai mulai memusatkan perhatian pada berbagai permasalahan sosial Indonesia. Seperti misalkan, konsumerisme, perusakan lingkungan dan kesehatan. Seperti yang dikemukakan dalam Mikhlouho (1997, hlm.95) bahwa :

Awal 80-an, beberapa seniman mantan gerakan seni rupa baru Gendut Riyanto, Harris Purnama, Harssono, dan Moelyono, sembari terus membahas segala yang seni, jatuh hati pada permasalahan lingkungan dan merasa perlu untuk menanganinya. Tahun 1984, di Galeri Seni Sono Yogya, kelima seniman itu membahas bagaimana caranya untuk memasukkan isu lingkungan ke dalam karya seni rupa. Pada tahun 1985 , kelima seniman tersebut bekerja sama dengan WALHI (Wahana Lingkungan Hidup Indonesia) mengadakan pameran dokumentasi foto dan poster bertemakan 
kerusakan lingkungan di Indonesia. Diantaranya pencemaran air dan udara, terutama peracunan sungai-sungai oleh limbah industri, dan akibatnya pada kesehatan masyarakat, terutama anakanak. Tema lainnya adalah perusakan hutan dan pencemaran karena sampah.

Konsep seni lingkungan juga dikenal dengan gerakan seni indigenous, pada saat itu counter culture atau gerakan ke lingkungan akan sedang dirasakan oleh generasi muda. Lebih lanjut Moelyana (1997, hlm.55-56) mengemukakan bahwa :

Istilah indigenous juga bisa mencakup objek-objek tradisional, seperti keahlian tradisional yang juga bisa tergolong desain kontemporer, misalnya tembikar, tenunan, kertas daur ulang, kerajinan perak, celupan kain, kerajinan lidi, dan lain-lainnya. Juga objek lainnya yang bisa didapatkan dalam lingkungan sekitar si seniman atau penciptanya. Mother nature menjadi sumbangan material seni yang tak habis-habisnya untuk menciptakan karya seni rupa instalasi. Material seni yang dideskripsikan sebagai mix media. Para seniman juga dapat bereksperimentasi dengan sampah seperti botol-botol plastik, mainan plastik, tas plastik, sandal jepit.

Seharusnya seni lukis dari limbah pelepah pisang ini dapat dijadikan sebagai lapangan pekerjaan bagi masyarakat Cimahi terutama bagi warga disekitar Jalan Amir Mahmud. Akan tetapi pada kenyataannya seni lukis dari limbah pelepah pisang ini tidak dapat dijadikan sebagai lapangan pekerjaan. Hal ini dikarenakan Kurangnya kesadaran dari masyarakat dalam melihat potensi dari seni lukis dari limbah pelepah pisang ini, sehingga seni lukis dari limbah pelepah pisang ini tidak dapat berkembang. Dalam hal ini masyarakat di Cimahi hanya sekedar ikut-ikutan dan tidak serius untuk mengembangkan seni lukis dari limbah pelepah pisang ini. Sehingga sampai saat ini pelukis yang menekuni seni lukis ini hanya beberapa saja. Berbanding terbalik dengan orang-orang dari luar daerah Cimahi, justru mereka berhasil mengembangkan keahliannya dalam memanfaatkan limbah dari pelepah pisang untuk dijadikan sebagai karya seni atau kerajinan tangan. Padahal jika dilihat masih ada pemuda atau warga yang menganggur tidak memiliki pekerjaan. Jika mereka serius untuk belajar dan menekuni seni lukis pelepah pisang maka seni lukis ini dapat dijadikan lapangan pekerjaan.

\section{Kesimpulan}

Seni lukis dari limbah pelepah pisang ini telah ada sejak tahun 1969. Seni lukis ini merupakan hasil kreativitas salah seorang warga Cimahi yaitu Ade Moelyana. Berawal dari keprihatinan dalam melihat limbah pelepah pisang yang berserakan dan tidak memiliki arti. Melalui kreativitasnya limbah dari pelepah pisang ini diubah menjadi karya seni yang memiliki potensi ekonomi yang cukup menjanjikan. Pada awal perkembangannya, seni lukis dari limbah pelepah pisang ini tidak serta merta dapat diterima oleh masyarakat disekitar Cimahi. Banyak yang beranggapan bahwa seni lukis ini aneh dan hanyalah sampah semata, akan tetapi karena ketekunan dan kerja keras pelukis akhirnya seni lukis dari limbah pelepah pisang ini dapat diterima oleh masyarakat sekitar bahkan banyak warga yang mulai belajar melukis dengan menggunakan limbah pelepah pisang.

Seni lukis dari limbah pelepah pisang ini tidak hanya diminati oleh warga lokal saja, akan tetapi seni lukis ini juga diminati oleh warga asing yang sedang melakukan 
wisata ke Indonesia. Seni lukis dari limbah pelepah pisang ini dapat dikategorikan sebagai salah satu sektor ekonomi kreatif. Hal ini karena seni lukis ini merupakan hasil kreativitas yang dihasilkan dari limbah pelepah pisang menjadi karya seni. Ekonomi kreatif diharapkan mampu menjawab tantangan isu global warming, karena perkembangan industri kreatif ini akan menuju pola ramah lingkungan. Hal ini telah dibuktikan dengan adanya seni lukis dari limbah pelepah pisang. Seni lukis dari limbah pelepah pisang ini dapat dikategorikan sebagai ekonomi kreatif dan mampu menjawab tantangan isu global warming. Hal ini dikarenakan dalam pembuatan seni lukis pelepah pisang ini menggunakan limbah dari pelepah pisang yang sudah tidak terpakai. Limbah tersebut lalu diubah menjadi suatu karya seni yang memiliki nilai ekonomi yang cukup menjanjikan. Pembuatan seni lukis dari limbah pelepah pisang ini benarbenar sangat ramah lingkungan, karena dalam pembuatannya hanya sedikit menggunakan bahan kimia, yaitu seperti lem kayu.

Dalam hal ini seni lukis dari limbah pelepah pisang dapat dijadikan sebagai potensi ekonomi kreatif yang memberikan peluang lapangan pekerjaan bagi masyarakat kota Cimahi khususnya bagi warga di sekitar Jalan Amir Mahmud. Selain itu pula seni lukis ini dapat dijadikan sebagai usaha budaya di kota Cimahi. Pembinaan keterampilan pun diberikan kepada masyarakat sekitar guna turut serta dalam mengembangkan seni lukis dari limbah pelepah pisang. Pembinaan dilakukan agar seni lukis dari limbah pelepah pisang agar tetap bertahan di Cimahi. Pembinaan ini banyak diikuti oleh berbagai orang yang tidak hanya berasal dari Cimahi saja, melainkan dari luar Cimahi seperti Garut, Tasik, Banjar, Cianjur, Semarang dll. Dalam hal ini banyak juga orang-orang yang telah belajar di Cimahi, mereka memilih mengembangkan seni lukis dari limbah pelepah pisang di daerahnya masing-masing.

\section{Daftar Pustaka}

Abdurahman, D. (2007). Metodologi penulisan sejarah. Jogjakarta: ARRUZZ MEDI A.

Ismaun. (2005). Pengantar Sejarah Sebagai Ilmu dan Wahana Pendidikan. Bandung: Historia Utama Press

Kartika, D. S. (2004). Seni rupa modern. Bandung : Rekayasa Sains.

Miklouho, B.(1998). Menguak luka masyarakat beberapa aspek seni rupa kontemporer Indonesia sejak 1996. Jakarta : PT Gramedia.

Moelyono. (1997). Seni rupa penyadaran. Yogyakarta: Yayasan Bentang Budaya.

Susanto, Mikke. (2002). Diksi rupa : kumpulan istilah seni rupa. Yogyakarta : Kanisius.

Suryana. (2013). Ekonomi kreatif ekonomi baru : mengubah ide dan menciptakan peluang. Jakarta : Salemba Empat.

Yuliman, S. (2001). Dua seni rupa sepilihan tulisan Sanento Yuliman. Jakarta: Yayasan Kalam.

Wawancara

Ade Moelyana (pelukis pelepah pisang di Cimahi)

Dani (asisten Ade Moelyana) 